\title{
PARAMETER POPULASI UDANG PUTIH (Penaeus merguiensis) DI PERAIRAN SAMPIT DAN SEKITARNYA, KALIMANTAN TENGAH
}

\section{POPULATION PARAMETERS OF WHITE SHRIMP (Penaeus merguiensis) IN SAMPIT AND ADJACENT WATERS, CENTRAL KALIMANTAN}

\author{
Erfind Nurdin dan Duranta D Kembaren \\ Balai Penelitian Perikanan Laut, Jakarta \\ Teregistrasi I tanggal: 04 Desember 2013; Diterima setelah perbaikan tanggal: 05 Agustus 2015; \\ Disetujui terbit tanggal: 10 Agustus 2015 \\ e-mail: erfind_nurdin@yahoo.co.id
}

\begin{abstract}
ABSTRAK
Udang putih (Penaeus merguiensis) merupakan salah satu sumberdaya ekonomis penting di perairan Sampit. Pada saat ini alat tangkap yang efisien untuk menangkap udang adalah lampara dasar (danishseine) dan jaring tiga lapis (trammel net). Penelitian tentang tingkat pengusahaan udang putih telah dilakukan dari bulan Januari sampai bulan Nopember 2012. Penilaian estimasi parameter populasi udang putih menggunakan paket program "FAO - ICLARM Stock Assessment Tools" atau FISAT - II. Hasil analisis diperoleh nilai laju pertumbuhan (K) sebesar 1,45 per tahun dengan panjang karapas asimtotik (CL”) 57,8 mm. Laju kematian total (Z) sebesar 5,70 per tahun, laju kematian alamiah (M) sebesar 1,93 per tahun dan laju kematian akibat penangkapan (F) sebesar 3,77 per tahun. Tingkat pengusahaan udang putih di perairan Sampit telah mengalami lebih tangkap (over exploited) dengan nilai E sebesar 0,66. Udang putih sudah tertangkap terlebih dahulu sebelum mencapai ukuran pertama kali matang gonad ( $\mathrm{Lc}=30,05<\mathrm{Lm}=39,4 \mathrm{mmCL}$ ). Kondisi ini mengindikasikan perlunya dilakukan pengelolaan yang hati-hati dan bertanggungjawab. Salah satu cara yang dapat ditempuh adalah dengan menerapkan sistem penutupan musim tangkapan, khususnya pada bulan Maret dan September, karena pada saat tersebut terjadi puncak pemijahan.
\end{abstract}

KATA KUNCI: Parameter populasi, udang putih, Sampit

\section{ABSTRACT}

White shrimp (Penaeus merguiensis) is one of the most valuable resources in the Sampit waters. At present danish seine and trammel net is an efficient gear available to catch shrimp. A study of exploitation of white shrimp was carried out from January to November 2012. Estimation of population parameter of white shrimp were analyzed by using program "FAO - ICLARM Stock Assessment Tools (FiSAT-II). The result showed that the value of growth rate $(K)$ was 1.45/year with asymptotic carapace length (CL") was $57.8 \mathrm{~mm}$. Total mortality rate $(Z)$ was 5.70/year, natural mortality rate $(M)$ was 1.93/year and fishing mortality rate $(F)$ was 3.77/year. Exploitation rate of white shrimp indicated overexploited $(E=0.66)$. Moreover, these shrimp was fished before reaching the first size on maturity $(L c=30.05<L m=39.4 C L m m)$. This condition indicate that it is necessary to manage shrimp fisheries carefully and responsibly. It is recommended to apply a closed season system, especially on March and September when peak of spawning season occurred.

KEYWORDS: Population parameter, white shrimp, Sampit

\section{PENDAHULUAN}

Kalimantan Tengah merupakan salah satu provinsi di Pulau Kalimantan yang berbatasan langsung dengan perairan Laut Jawa dengan panjang garis pantai sekitar $750 \mathrm{~km}$. Salah satu sentra perikanan udang di Kalimantan Tengah terdapat di muara Sungai Mentaya Desa Sei Ijum Raya yang merupakan bagian dari Kabupaten Kotawaringin Timur. Menurut Anonimus (2011) produksi udang pada tahun 2011 di Kabupaten Kotawaringin Timur mencapai 1034,1 ton atau setara dengan 30,9\% dari total produksi perikanan provinsi Kalimantan Tengah. Jenis Korespondensi penulis:

Balai Penelitian Perikanan Laut-Muara Baru, Jakarta

Jl. Muara Baru Ujung, Komp. PPS Nizam Zachman-Jakarta Utara udang yang cukup dominan adalah udang putih/putih (Penaeus merguiensis). Produksi hasil tangkapan udang putih di perairan Sampit pada tahun 2009 sebesar 188,9 ton dan mengalami peningkatan menjadi 199,4 ton (2010) dan 287 ton (2011).

Udang putih dalam bahasa internasional disebut dengan white shrimp, umumnya ditangkap dengan menggunakan trawl, jaring tiga lapis (trammel net), lampara dasar (danish seine), jaring dogol, belat dan sero (Subani \& Barus, 1988). Di perairan Sampit, udang putih ditangkap dengan menggunakan jaring tiga lapis 
dan lampara dasar yang dioperasikan dengan menggunakan perahu motor berukuran kurang dari $5 \mathrm{GT}$. Ukuran mata jaring bagian kantong lampara dasar sebesar 1,5 dan 1,25 inci, sementara itu ukuran mata jaring trammel net sebesar 1,75 inci pada bagian dalam (inner net) dan 10 inci pada bagian luar (outer net) (Anonimus, 2012).

Suman \& Umar (2010) menyatakan bahwa sumberdaya udang perlu mendapat perhatian yang serius dengan upaya-upaya pengelolaan yang lebih baik. Walaupun sumber daya udang termasuk sumber daya yang dapat pulih (renewable resources) tetapi penangkapan yang terus meningkat tanpa adanya pembatasan akan menyebabkan habisnya sumberdaya tersebut.

Mengingat tingginya intensitas penangkapan udang di wilayah ini yang dilakukan sepanjang tahun, maka dikhawatirkan pemanfaatannya akan mengancam kelestarian dan keberlanjutan pemanfaatan sumber daya tersebut. Apalagi hal ini terjadi pada sumber daya udang yang sangat rentan terhadap dampak penangkapan mengingat sifatnya yang memiliki ruaya yang sempit, aktivitas rendah dan kawanan relatif kecil (Aoyama, 1973 dalam Suman \& Umar, 2010).

Penelitian tentang dinamika populasi udang putih telah dilakukan di beberapa perairan di Indonesia seperti perairan Arafura (Naamin, 1984), Cilacap (Suman, 1992; Suman\&Boer, 2005; Saputra, 2005; Saputra \& Subiyanto, 2007), Madura Strait (Setyohadi et al., 1999), Kotabaru (Suman \& Umar, 2010) dan di Bone (Kembaren et al., 2012).

Perkembangan udang sebagai target penangkapan mendorong peningkatan upaya penangkapan yang terus menerus. Hal ini disebabkan oleh permintaan pasar dan nilai komersil dari udang yang meningkat. Tindakan pengelolaan yang rasional perlu dilakukan agar sumberdaya udang mampu berada dalam keseimbangan yang lestari. Estimasi parameter populasi diperlukan sebagai data dan informasi pendukung dalam pengelolaan tersebut.

\section{BAHANDANMETODE Pengumpulan Data}

Penelitian udang putih/putih (Penaeus merguiensis) dilakukan di perairan Sampit, Kalimantan Tengah pada bulan Januari sampai dengan November tahun 2012. Sampel udang diperoleh dari hasil tangkapan lampara dasar yang di daratkan di muara Sungai Mentaya Desa Sei Ijum Raya Kecamatan Mentaya Hilir Selatan, Teluk Sampit Kabupaten Kotawaringin Timur

Pengukuran udang dilakukan oleh tenaga enumerator lapangan yang telah di latih tentang pengenalan jenis udang dan metode sampling biologi. Jumlah sampel yang diukur berjumlah seratus ekor dalam setiap bulannya.

Pengamatan biometrik meliputi pengkuran panjang karapas, dilakukan dengan menggunakan jangka sorong (tingkat ketelitian 0,01 mm). Data panjang karapas yang diperoleh kemudian ditabulasikan dalam tabel distribusi frekuensi panjang karapas dengan interval $2 \mathrm{~mm}$ menggunakan bantuan program Microsoft Excel. Pengamatan berat dilakukan dengan menggunakan bantuan alat timbangan digital dengan tingkat ketelitian 0,5 gram.

Tingkat kematangan gonad udang putih ditentukan secara morfologik sesuai dengan kriteria tingkat indeks kematangan gonad udang yang dikemukakan oleh Naamin (1984) yaitu: (1) dara (undeveloped), (2) berkembang (developed), (3) hampir matang (early mature), (4) matang (ripe) dan (5) salin (spent). Tingkat kematangan gonad 1 dan 2 dikelompokan dalam golongan belum matang dan tingkat kematangan gonad 3 dan 4 sebagai golongan matang gonad.

\section{Analisis Data}

Parameter pertumbuhan ( $\mathrm{K}$ dan $\mathrm{L} \infty$ ) dirunut dengan menggunakan metode Electronic Length Frequency Analysis (ELEFAN) dalam paket program FiSAT (Gayanilo et al., 2005). Informasi tentang parameter populasi diperoleh dengan analisis data ukuran panjang karapas, berat dan tingkat kematangan gonado. Pendugaan laju kematian total $(\mathrm{Z})$ dianalisis dengan menggunakan "catch curve" (Gayanilo et al., 2005), sedangkan laju kematian alamiah (M) diduga dengan menggunakan rumus empiris Pauly (1983) yang menggunakan data rata-rata suhu permukaan perairan tahunan $(\mathrm{T})$ sebagai berikut:

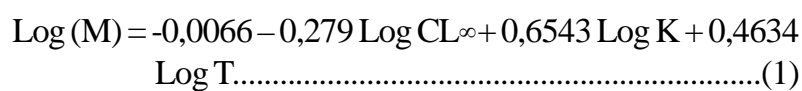

Pendugaan mortalitas total (Z) dilakukan dengan metode kurva konversi hasil tangkapan dengan panjang (length converted catch curve) pada paket program FiSAT-II (Pauly, 1983; Gayalino et al., 2005). Mortalitas penangkapan (F) dan laju eksploitasi (E) dihitung dengan rumus (Pauly, 1983) :

$\mathrm{F}=\mathrm{Z}-\mathrm{M}$ dan $\mathrm{E}=\mathrm{F} / \mathrm{Z}$

Penentuan panjang pertama kali matang gonada (Lm) menggunakan pendekatan rumus Spearman Karber (Udupa, 1986):

$m=X_{k}+\frac{x}{2}-\left(X \sum_{i}^{n} 1 p i\right) \cdots$ 
dimana:

$\mathrm{m}=\log$ ukuran udang saat pertama matang ovarium;

$\mathrm{Xk}=$ log ukuran udang dimana $100 \%$ udang contoh sudah matang;

$\mathrm{X} \quad=$ selang log ukuran (log size increment);

pi $\quad=$ proporsi udang matang pada kelompok ke-i;

Ukuran rata-rata udang pertama kali matang gonad diperoleh dari nilai $\operatorname{antilog}(\mathrm{m})$.

Parameter pertumbuhan udang putih diolah dari data pergeseran modus sebaran frekuensi panjang karapas dalam satu runut waktu menggunakan kurva pertumbuhan von Bertalanffy. Selanjutnya kurva yang melalui modus paling banyak akan menggambarkan pola pertumbuhan (Sparre \& Venema, 1999).

\section{HASIL DAN BAHASAN HASIL}

\section{Parameter Pertumbuhan}

Pengukuran terhadap jenis udang putih yang dilakukan tidak membedakan jenis kelamin. Hasil pengukuran frekuensi panjang karapas - carapace length (CL) diperoleh 872 ekor sampel udang, dimulai pada nilai tengah (mid length) 18 hingga $58 \mathrm{~mm}$, dengan sebaran panjang karapas tertinggi pada modus 32 dan 34 mmCL sebesar $15,02 \%$ dan 20,30\% seperti disajikan pada Gambar 1.

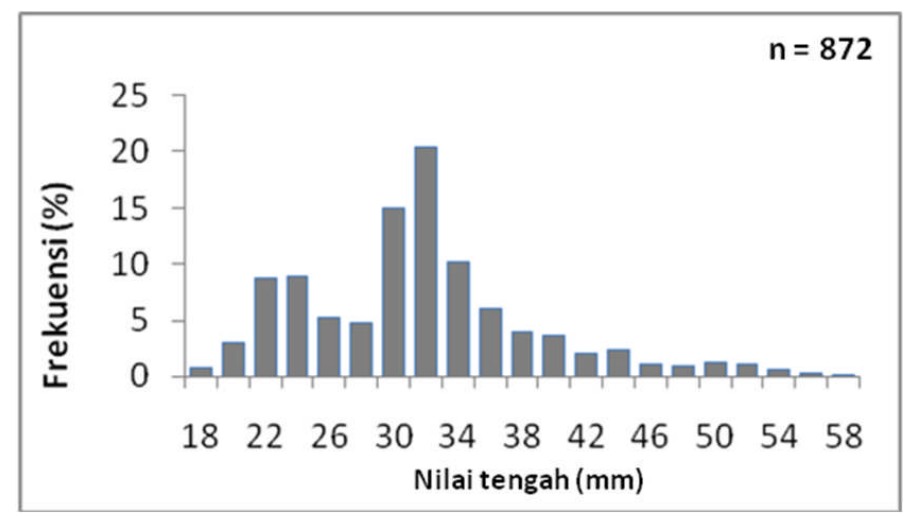

Gambar 1. Sebaran panjang karapas udang putih di perairan Sampit, Januari-November 2012.

Figure 1. Carapace length distribution of white shrimp in Sampit waters January-November 2012.

Gambar 2 menyajikan data sebaran frekuensi panjang karapas udang putih di perairan Sampit. Analisa menggunakan program ELEFAN diperoleh panjang karapas asimtotik (L ) sebesar 57,8 mm dengan laju pertumbuhan $(\mathrm{K})$ sebesar 1,45 per tahun.

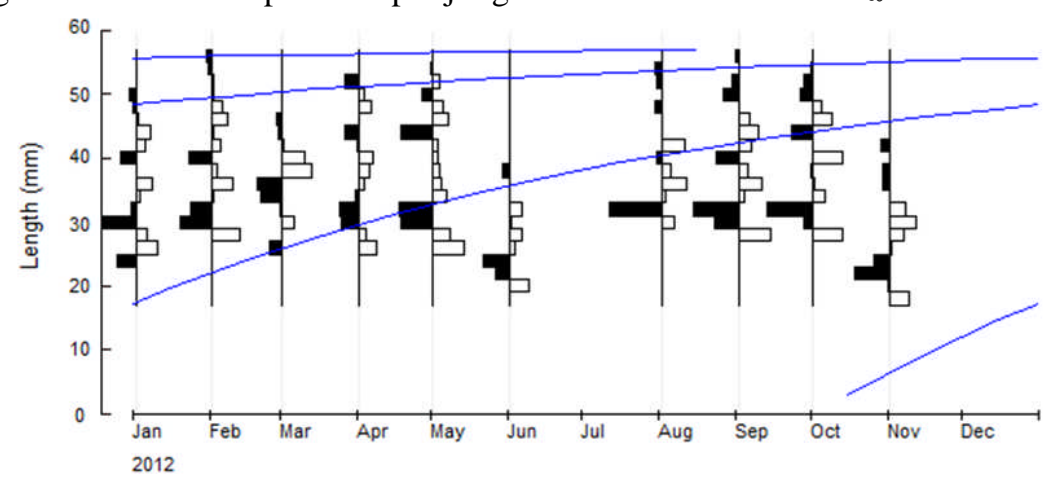

Gambar 2. Kurva pertumbuhan udang putih di perairan Sampit, 2012.

Figure 2. Growth curve of white shrimp in Sampit waters, 2012.

Hasil analisa parameter populasi menunjukkan bahwa laju kematian alamiah (M) udang putih sebesar 1,93 per tahun, laju kematian akibat penangkapan (F) sebesar 3,77 per tahun, dan laju kematian total sebesar (Z) 5,70 per tahun. Kurva hasil tangkapan yang dilinierkan berdasarkan panjang karapas dengan kemiringan (slope) sebagai nilai Z dijelaskan pada Gambar 3.
Tingkat pengusahaan (E) udang putih di perairan Sampit yang merupakan perbandingan antara nilai $\mathrm{F}$ dan $\mathrm{Z}$ diperoleh sebesar 0,66. Hal ini menunjukkan bahwa laju pengusahaan sudah melebihi nilai optimum dimana nilai $\mathrm{E}$ yang disarankan oleh Pauly (1983) sebesar 0,5. 
Pendugaan Rata-rata Ukuran Matang Kelamin (Lm) dan Rata-rata Ukuran Tertangkap (Lc)

Berdasarkan metode Spearman-Karber (Udupa, 1986) diperoleh panjang pertama kali matang gonada (length at first maturity- $\mathrm{Lm}$ ) pada ukuran 39,4 mmCL. Nilai panjang pertama kali tertangkap (length at first capture-Lc) dimana menunjukkan dimana 50\% dari udang yang ditangkap jaring terdapat pada ukuran 30,05 mm. Kurva yang menunjukkan seleksi alat tangkap (lampara dasar) terhadap populasi udang yang tertangkap disajikan pada Gambar 4. Dari hasil ini dapat diketahui bahwa nilai $\mathrm{Lc}<\mathrm{Lm}$.

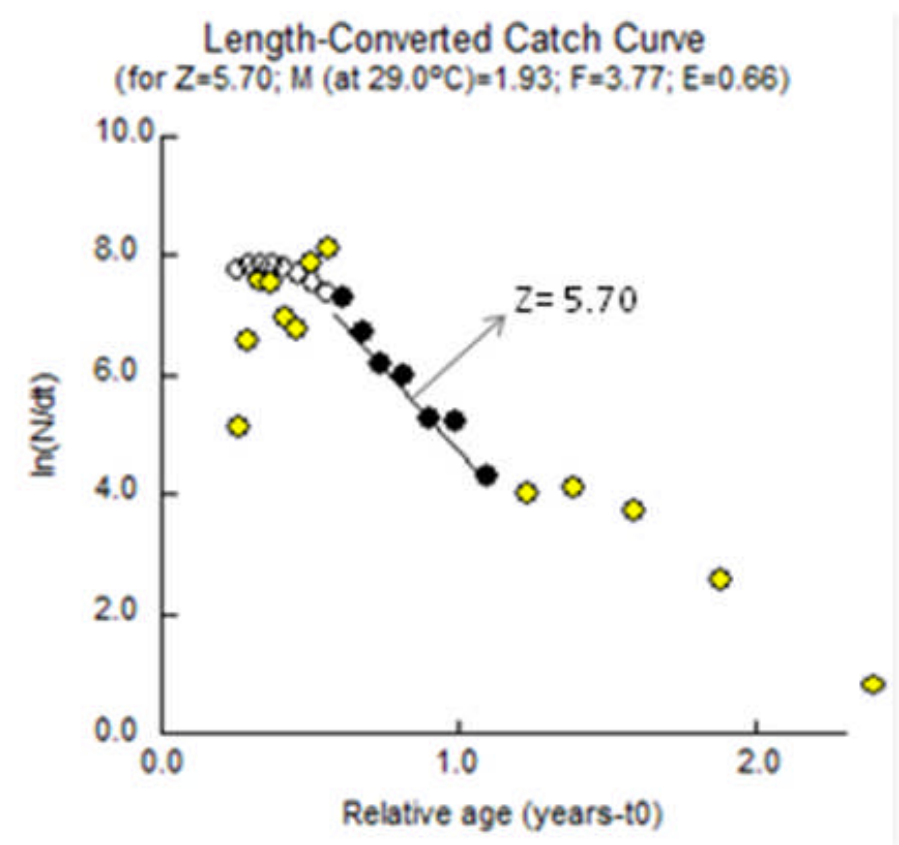

Gambar 3. Kurva hasil tangkapan udang putih berdasarkan data panjang yang dilinierkan di perairan Sampit, 2012. Figure 3. Length converted catch curve of white shrimp in Sampit waters, 2012.

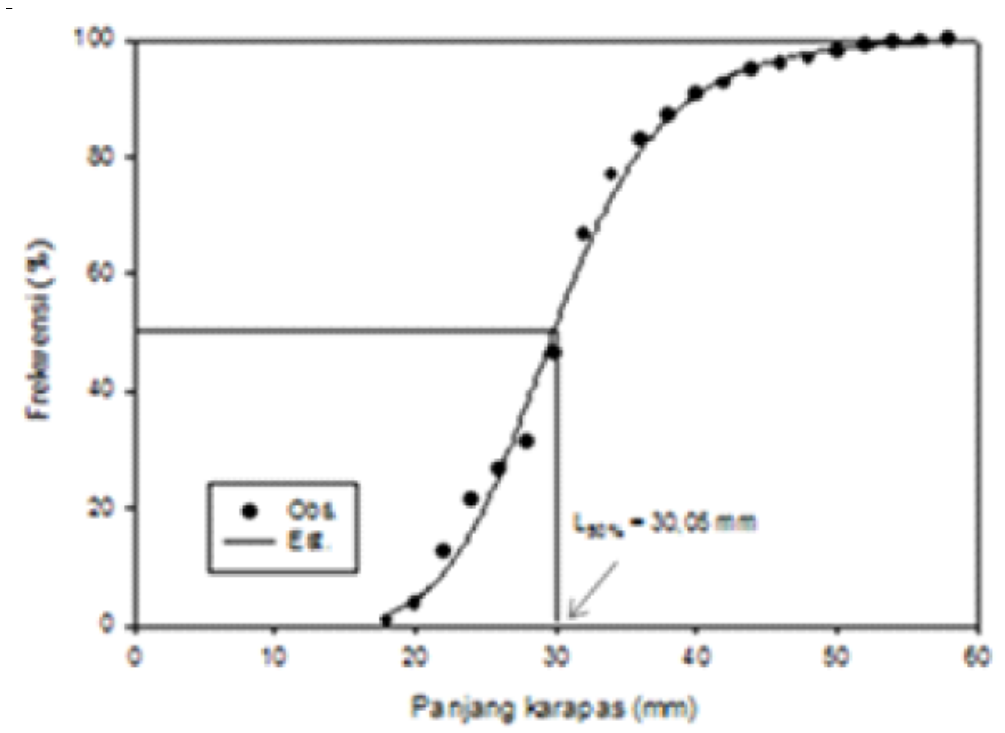

Gambar 4. Kurva seleksi alat tangkap lampara dasar terhadap udang putih di perairan Sampit.

Figure 4. Selection curve of danish seine for shrimp caught in Sampit waters.

\section{Dugaan Musim Pemijahan}

Musim pemijahan udang putih di perairan Sampit diperoleh dari pengamatan bulanan terhadap tingkat kematangan gonada (TKG) udang betina. Diduga udang putih menijah sepanjang tahun dengan puncak musim pemijahan terjadi pada bulan Maret dan September (Gambar 5). 


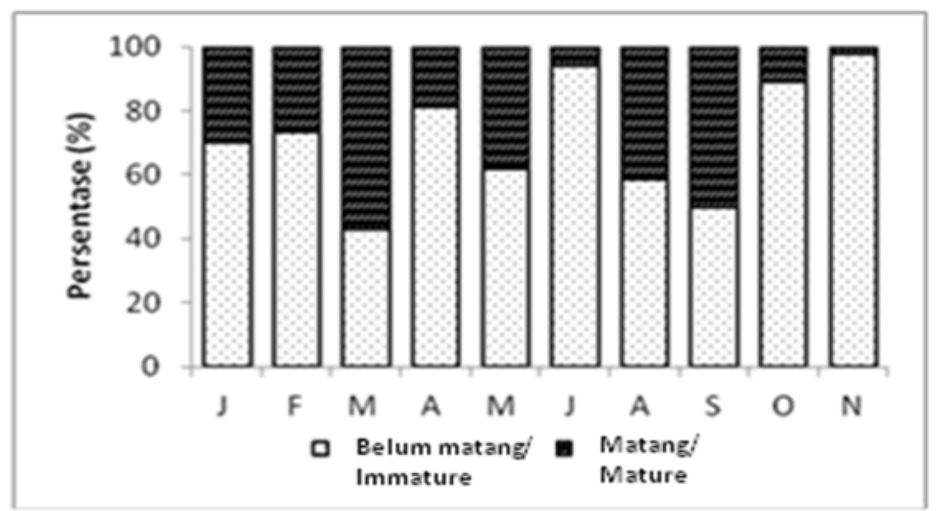

Gambar 5. Sebaran bulanan TKG udang putih di perairan Sampit.

Figure 5. Monthly distribution of gonadal maturity of white shrimp in Sampit waters.

\section{BAHASAN}

Hasil penelitian menunjukkan bahwa panjang karapas asimtotik (L") dan laju pertumbuhan (K) udang putih di perairan ini masing-masing sebesar $57,8 \mathrm{~mm}$ per tahun dan 1,45 per tahun. Panjang karapas asimtotik dan laju pertumbuhan udang putih di perairan Kotabaru sebesar 44,3 mm dan 1,4/tahun (Suman \& Umar, 2010), di perairan Cilacap sebesar 37,5 mm dan 1,4/tahun (Saputra \& Subiyanto, 2007) dan di perairan Bone sebesar $39 \mathrm{~mm}$ dan 1,2/tahun (Kembaren et al., 2012). Dibandingkan dengan udang putih dari perairan tersebut tampak bahwa udang putih di perairan Sampit mampu mencapai ukuran yang lebih besar. Menurut Effendi (1997), perbedaan pertumbuhan tersebut diduga karena kelimpahan makanan yang berbeda dan pengaruh kondisi lingkungan perairan pada masing-masing lokasi penelitian.

Secara umum laju kematian udang putih di perairan ini tidak berbeda jauh dengan laju kematian udang putih di perairan lainnya. Kematian total (Z) udang putih di perairan Kotabaru sebesar 4,52/tahun, laju kematian alami 1,96/tahun, laju kemataian penangkapan 2,56/tahun (Suman \& Umar, 2010). Penelitian di perairan Cilacap diperoleh laju kematian total udang putih sebesar 7,02/ tahun, laju kematian alami 1,96/tahun, dan laju kemataian karena penangkapan 5,06/tahun (Saputra \& Subiyanto, 2007). Sementara itu, hasil penelitian Kembaren et al., (2012) di perarian Bone menunjukkan bahwa laju kematian total, laju kematian alami dan laju kematian penangkapan udang putih secara berurutan masing-masing sebesar 7,86/ tahun, 1,90/tahun dan 5,96/tahun.

Perberdaan nilai laju kematian udang putih di masingmasing lokasi penelitian diduga kuat dipengaruhi oleh perbedaan besarnya upaya penangkapan yang dilakukan dan kemampuan operasional penangkapan dari alat tangkap yang digunakan. Menurut Suman \& Umar (2010), laju kematian karena penangkapan $(\mathrm{F})$ tergantung dan bervariasi menurut keragaman upaya penangkapan setiap tahunnya
Tingkat pengusahaan (E) udang putih di perairan Sampit sebesar 0,66. Nilai ini lebih besar dari nilai E optimum yaitu 0,5 . Dapat dikatakan bahwa laju pengusahaannya sudah melebihi batas pemanfaatan yang optimal. Hal ini didukung pula oleh laju kematian akibat penangkapan yang cukup tinggi dibandingkan kematian alaminya. Disamping itu, udang hasil tangkapan didominasi oleh udang yang belum layak tangkap dimana ukuran pertama kali tertangkap (Lc) lebih kecil dibandingkan dengan ukuran pertama kali matang gonada (Lm).

Nilai laju pengusahaan di perairan ini lebih besar daripada yang ditemukan di perairan Kotabaru $(E=0,56)$ dan lebih kecil dari perairan Segara Anakan $(\mathrm{E}=0,72)$ dan Bone ( $\mathrm{E}=0$,76). (Suman \& Umar, 2010; Saputra \& Subiyanto, 2007; Kembaren et al., 2012).

Laju pengusahaan merupakan gambaran dari nilai laju kematian akibat upaya penangkapan (eksploitasi) dibandingkan dengan nilai kematian total (alami dan eksploitasi). Perbedaan nilai laju pengusahaan di setiap lokasi diduga terjadi karena tingkat eksploitasi upaya penangkapan yang berbeda pada masing-masing lokasi. Tingginya nilai laju pengusahaan ini menunjukkan bahwa tindakan pengelolaan harus dilakukan secara hati-hati agar kelestarian sumberdaya udang berlanjut.

Pengamatan di perairan Sampit menunjukkan udang putih yang tertangkap didominasi oleh udang yang relative masih muda yaitu pada ukuran panjang karapas $32 \mathrm{~mm}$. Rata-rata ukuran panjang pertama kali tertangkap juga lebih kecil dari rata-rata ukuran panjang pertama kali matang gonad (Lc $<\mathrm{Lm}$ ). Hal ini mengindikasikan bahwa udang sudah tertangkap sebelum melakukan proses pemijahan. Saputra et al. (2013) menyatakan bahwa banyak udang putih di Cilacap tertangkap sebelum matang gonada yang didominasi oleh TKG I sebesar $85,35 \%$. Jika dibiarkan terus hal ini dapat menyebabkan penurunan stok udang. Menurut Hargiyatno et al. (2013), hal serupa juga terjadi di perairan Dolak dimana rata-rata ukuran panjang pertama 
kali tertangkap (28,78 mmCL) juga lebih kecil dari rata-rata ukuran panjang pertama kali matang gonad (38,7 mmCL)

Hasil analisa menunjukkan bahwa musim pemijahan udang putih terjadi sepanjang tahun, namun demikian puncak pemijahan diduga terjadi pada bulan Maret dan September dimana pada bulan-bulan tersebut persentase udang yang matang gonad lebih tinggi dibanding bulanbulan lainnya. Hal yang sama juga diperoleh di perairan Tarakan, dimana puncak musim pemijahan juga terjadi pada bulan Maret dan September (Kembaren \& Suman, 2013). Namun hal ini berbeda dengan yang ditemukan di perairan Pemangkat yang mengalami puncak musim pemijahan pada bulan November (Kembaren, 2013). Perbedaan ini disebabkan oleh perbedaan kondisi geografis yang berpengaruh pada kondisi curah hujan di masing-masing lokasi. Menurut Naamin (1984), curah hujan berhubungan dengan puncak musim bertelur udang yang biasanya terjadi pada awal dan akhir musim penghujan.

Berdasarkan hasil tersebut, maka disarankan untuk mengurangi upaya penangkapan dari upaya pada saat ini atau melakukan penutupan penangkapan pada bulan Maret dan September. Pada bulan tersebut diduga merupakan puncak musim pemijahan udang putih di perairan ini. Dengan demikian diharapkan proses regenerasi udang dapat kembali normal pada bulan berikutnya.

\section{KESIMPULAN}

Analisa parameter populasi udang putih (Panaeus merguensis) di perairan Sampit diperoleh laju pertumbuhan (K) sebesar 1,45 per tahun, laju kematian alamiah (M) sebesar 1,93 per tahun, laju kematian akibat penangkapan (F) sebesar 3,77 per tahun dan laju kematian total sebesar (Z) 5,70 per tahun. Diperoleh tingkat pengusahaan (E) sebesar 0,66 atau melebihi tingkat optimal yang besarnya 0,5 . Musim pemijahan udang putih berlangsung sepanjang tahun dengan puncaknya terjadi pada bulan Maret dan September. Disarankan untuk melakukan penutupan musim penangkapan pada bulan tersebut.

\section{PERSANTUNAN}

Tulisan ini merupakan kontribusi dari kegiatan riset sumberdaya udang dan krustasea lainnya di Laut Jawa dan Laut Sulawesi tahun anggaran 2012 di Balai Penelitian Perikanan Laut, Jakarta.

\section{DAFTAR PUSTAKA}

Anonimus. 2012. Laporan Akhir Pengkajian Stok dan Pengusahaan Sumber Daya Udang Penaeid dan Rajungan di Wilayah Pengelolaan Perikanan (WPP)
712 Laut Jawa dan 716 Laut Sulawesi. Balai Penelitian Perikanan Laut Jakarta: 132 hal (Tidak dipublikasikan).

Anonimus. 2011. Statistik Perikanan Tangkap Provinsi Kalimantan Tengah 2007 - 2011. (Diterbitkan setiap tahun).

Effendie, M I. 1997. Biologi Perikanan. Penerbit Yayasan Pustaka Nusatama. Yogyakarta: 163 hal.

Gayanilo, F. C. Jr., P. Sparre \& D. Pauly. 2005. FAOICLARM Stock Assessment Tools II (FiSAT II). Revised version.User's guide. FAO Computerized Information Series (Fisheries). No. 8. Revised version. FAO Rome: 168p.

Gulland, J. A. 1983. Fish stock assesment. A Manual of Basic Methods. John Wiley \& Sons. Chicester: 233 pp.

Hargiyatno, I.T, Sumiono, B \& Suharyanto. 2013. Laju Tangkap, Kepadatan Stok, dan Beberapa Aspek Biologi Udang Putih (Penaeus merguiensis) di Perairan Dolak, Laut Arafuru. Bawal - Widya Riset. Pusat Penelitian Pengelolaan Perikanan dan Konservasi Sumberdaya Ikan. Vol 5(2): 123-129.

Kembaren, D.D., B. Sumiono, \& Suprapto. 2012. Biologi dan parameter pertumbuhan udang putih (Penaeus merguiensis) di perairan Bone, Sulawesi Selatan. Dalam Suman, A., Wudianto dan B. Sumiono (Ed.): Status pemanfaatan sumberdaya ikan di perairan Selat Makassar, Teluk Bone, Laut Flores dan Laut Banda. IPB Press. Bogor: 300 halaman.

Kembaren, D.D. 2013. Asepk biologi udang putih (Penaeus merguiensis De Hann) di perairan Pemangkat, Kalimantan Barat. Widya riset LIPI. Vol. 6(3): 371-376.

Kembaren, D.D. \& A. Suman. 2013. Biology and population dynamics of white shrimp (Penaeus merguiensis) in the Tarakan waters, East Borneo. Ind. Fish. Res. J. Pusat Penelitian Pengelolaan Perikanan dan Konservasi Sumberdaya Ikan. Vol. 19 (2): 99 - 105.

King, M. 1995. Fisheries Biology, Ascessment and Management. Fishing News Books a Division of Blackwell Science Ltd, London: 151-156.

Naamin, N. 1984. Dinamika populasi udang putih (Penaeus merguiensis de Mann) di perairan Arafura dan alternatif pengelolaannya. Desertasi. Fakultas Pascasarjana. Institut Pertanian Bogor: 277 halaman. 
Pauly, D. 1983. Some Simple Methods for the Assessment of Tropical Fish Stocks.FAO Fisheries Technical Paper (254): 52p.

Saputra, S.W \& Subiyanto. 2007. Dinamika populasi udang putih (Penaeus merguiensis De Mann 1907) di Laguna Segara Anakan, Cilacap, Jawa Tengah. Ilmu Kelautan. Universitas Diponegoro. Vol 12 (3) : 157-166.

Saputra, S.W., Djuwito \& A Rutiyaningsih. 2013. Beberapa Aspek Biologi Udang Putih (Penaeus merguiensis) di Perairan Pantai Cilacap Jawa Tengah. Management of Aquatic Resources Journal. UNDIP. Vol 2 (3): 49-55.

Sparre, P. \& S. Venema. 1999. Introduction to Tropical Fish Stock Assesment. (IntroduksiPengkajian Stok
Ikan Tropis. Alih bahasa: Pusat Penelitian dan Pengembangan Perikanan). Buku 1: Manual. Badan Penelitian dan Pengembangan Perikanan. Jakarta: 438 halaman.

Subani, W. \& H.R. Barus. 1988. Alat penangkap ikan laut dan udang di perairan Indonsia. Jurnal Penelitian Perikanan Laut. Balai Penelitian Perikanan Laut Jakarta. (47): 21-30.

Suman, A \& C. Umar. 2010. Dinamika populasi udang putih (Penaeus merguiensis de Mann) di perairan Kotabaru, Kalimantan Selatan. J.Lit.Perikan Ind. Pusat Riset Perikanan Tangkap. 16 (1): 29-33.

Udupa, K.S. 1986. Statistical method of estimating the size of first maturity in fish. Fishbyte. 4(2): 8-11. 